\title{
MODEL PEMBELAJARAN ARIFIN, SEBUAH UPAYA MEMBANGUN REKONSILIASI PAHAM BEHAVIORISME DAN KONSTRUKTIVISME
}

\author{
Zaenal Arifin \\ ${ }^{\text {a } P r o g r a m ~ S t u d i ~ P e n d i d i k a n ~ M a t e m a t i k a ~ U n i v e r s i t a s ~ I s l a m ~ D a r u l ~ ' U l u m ~ L a m o n g a n, ~}$ \\ ari3f_t3a@yahoo.com, Jl. Airlangga No. 03 Sukodadi, Lamongan.
}

\begin{abstract}
Abstrak
Ditinjau dari cara pemerolehan pengetahuan oleh siswa, ada dua arus besar dalam teori pembelajaran. Kedua kelompok tersebut adalah aliran behaviorisme dan aliran konstruktivisme. Aliran behaviorisme sering dipandang sebagai aliran yang sudah usang (out of date), Aliran konstruktivisme saat ini banyak dianut oleh para ahli maupun kalangan praktisi pendidikan. Pertentangan dua paham ini tidak seharusnya terjadi. Secara objektif seharusnya perlu dilihat kontribusi masing-masing aliran tersebut dalam membangun kompetensi siswa. Kedua paham ini dapat digunakan secara proporsional serta sesuai kebutuhan dan tujuan pendidikan yang telah ditetapkan dalam kurikulum yang berlaku. Model ARIFIN adalah sebuah model pembelajaran temuan penulis, dengan langkah-langkah: action, reflection, interaction, formalization, interconnection, dan narration, dapat dijadikan sebagai alternatif sebagai konduktor dalam upaya membangun rekonsiliasi antara kedua aliran tersebut.
\end{abstract}

Kata kunci:behaviorisme, konstruktivisme, pemecahan masalah, komunitas inquiry matematika, Model ARIFIN

\begin{abstract}
Judging from the way students acquire knowledge, there are two major currents in learning theory. The two groups are the flow of behaviorism and constructivism. The flow of behaviorism is often seen as an outdated stream. The current flow of constructivism is widely embraced by experts and educational practitioners. This clash of two understandings should not occur. Objectively, it should be necessary to look at the contribution of each of these streams in building student competence. Both of these ideas can be used proportionally and according to the needs and educational goals set out in the applicable curriculum. The ARIFIN model is a learning model from the author's findings, with the following steps: action, reflection, interaction, formalization, interconnection, and narration, which can be used as an alternative as a conductor in an effort to build reconciliation between the two streams.
\end{abstract}

Keywords: behaviorism, constructivism, problem solving, mathematical inquiry community, ARIFIN Model 


\section{PENDAHULUAN}

Metode pengajaran adalah suatu alat khusus yang didesain untuk menunjukkan tipe pengajaran tertentu. Davis (1960) mengingatkan kita kepada fakta bahwa, setiap metode yang digunakan memiliki dua dampak yang tidak bisa dihindari, keuntungan (kelebihan) atau kelemahan. Tidak ada satu pun metode, dapat memenuhi semua keinginan, sehingga perlu untuk menggunakan beberapa teknik yang berbeda dalam penyampaian suatu materi pelajaran. Guru dapat memilih metode yang dapat ia adaptasikan pada situasi belajar siswa sesuai kebutuhan.

Pada perkembangan terakhir, pendidikan matematika di Indonesia belum menunjukkan perubahan yang berarti. Walaupun ada beberapa alasan yang menganggap perlu menonjolkan ciri khas ke-Indonesia-an, tetapi pandangan tersebut tidak boleh menghalangi munculnya orientasi tujuan yang bersifat universal. Beberapa kompetensi yang termasuk dalam tujuan pengajaran matematika secara khusus, seperti: Critical Thinking Skill, Creative Thinking Skill, dan Problem Solving Skill saat ini sudah menjadi orientasi utama pengajaran matematika di negara- negara maju.

Setidaknya ada dua aspek tujuan pengajaran matematika yang berlaku secara universal. Pertama, tujuan pengajaran matematika yang terkait dengan penguasaan konsep-konsep, prinsip-prinsip, fakta maupun skill matematika.. Kedua, tujuan pengajaran matematika yang lebih dari sekedar menguasai konsep-konsep, prinsip, fakta, atau skill, yaitu melatihkan keterampilan berpikir tingkat tinggi (berpikir kritis, kreatif, atau pemecahan masalah).

Ada banyak metode pengajaran matematika yang dianggap relevan untuk melatihkan keterampilan berpikir. Salah satunya adalah dengan membangun komunitas inquiry matematika dalam proses pembelajaran di kelas. Penulis memandang bahwa salah satu strategi yang relevan dengan tujuan ini adalah strategi ARIFIN (Aksi, Refleksi, Interaksi, Formalisasi, Interkoneksi, dan Narasi).

Berdasarkan uraian sebagaimana yang telah dikemukakan, dapat dikemukakan beberapa permasalahan yang akan menjadi pokok pembahasan dalam tulisan ini sebagai berikut: (1) Teori-teori belajar apa yang melandasai Model ARIFIN?; (2) Bagaimanakah relevansi Model ARIFIN dengan upaya membangun komunitas inquiry matematika?; (3) Bagaimanakah implikasi Strategi ARIFIN dalam proses pembelajaran matematika yang memadukan aliran behaviorisme dan konstruktivisme? 


\section{PEMBAHASAN}

Melalui proses pengajaran diharapkan tujuan utama agar siswa mampu memahami konsep matematika, prinsip-prinsip, fakta maupun skill dengan baik, dapat tercapai. Melalui berbagai kajian terhadap teori-teori belajar yang ada, penulis menciptakan (create) suatu strategi pengajaran (strategy of teaching) yang memiliki keterkaitan secara khusus dengan upaya membangun komunitas inquiry matematika dalam proses pembelajaran di kelas. Strategi tersebut terdiri dari 6 tahap yang merupakan satu rangkaian proses pembelajaran suatu konsep, prinsip atau skill matematika. Tahaptahap tersebut adalah Acting (melakukan aksi), Reflecting (melakukan refleksi), Interacting (berinteraksi), Formalizing (melakukan formalisasi), Interconnecting (menjalin interkoneksi), dan Narrating (bernarasi). Berdasarkan huruf awal dari keenam tahap tersebut, strategi ini penulis populerkan dengan istilah strategi ARIFIN .

\section{Munculnya gagasan Model} ARIFIN ini terinspirasi oleh hasil telaah kritis penulis terhadap beberapa temuan dalam studi tentang pembelajaran matematika di tingkat internasional. Beberapa kajian tersebut, ada yang cenderung cocok diterapkan pada siswa tingkat rendah, seperti pendekatan
Realistic Mathematics Education (RME) yang dirintis di Belanda dan Mathematics in Context (MiC) yang dikembangkan di United State of America (USA), ada pula kajian hasil studi pembelajaran matematika yang relevan dengan siswa pada level yang lebih tinggi, seperti teori APOS (Action, Process, Object, Schema). Berikut ini akan diuraikan secara terperinci beberapa teori belajar dan hasil-hasil studi yang relevan dengan Model ARIFIN .

\section{Pendekatan Konstruktivisme dalam Pembelajaran Matematika}

Suatu revolusi telah terjadi dalam psikologi pendidikan. Revolusi tersebut muncul dengan nama "teori pembelajaran konstruktivis". Ide utama dari teori ini adalah bahwa siswa harus secara mandiri menemukan dan mentransfer informasi-informasi apabila mereka menginginkan informasi tersebut menjadi miliknya. Dari perspektif pelaku proses pembelajaran, strategi kontruktivis sering disebut dengan "pengajaran berpusat kepada siswa" (student centered instruction). Dalam teori ini, guru berperan sebagai fasilitator bagi siswa untuk menemukan fakta, konsep, maupun prinsip secara mandiri, dan bukan memberikan ceramah atau mengambil alih seluruh kegiatan kelas (Slavin, 1997). Paham 
konstruktivisme lahir dari gagasan Piaget dan Vygotsky. Keduanya menekankan bahwa perubahan kognitif hanya terjadi jika konsepsi yang telah dipahami sebelumnya diolah melalui proses ketidakseimbangan dalam memahami informasi-informasi baru.

Ide konstruktivis modern banyak berlandaskan teori Vygotsky. Ada empat kunci utama yang diturunkan dari teori Vygotsky tersebut (Slavin, 1997). Pertama, teori ini menekankan kepada hakikat sosial dalam pembelajaran. Menurut teori ini siswa belajar melalui interaksi dengan orang dewasa atau teman sebaya. Kedua, siswa belajar konsep paling baik apabila konsep itu berada dalam zone of proximal development (zona perkembangan terdekat) mereka. Ketiga, teori ini menekankan kepada penggabungan dari hakikat sosial dan zona perkembangan terdekat, yaitu pemagangan kognitif (Gardner dalam Slavin, 1997). Keempat, teori ini menekankan bahwa scaffolding atau mediated learning sebagai suatu hal penting dalam pemikiran konstruktivis modern (Kozulin \& Presseisen dalam Slavin,1997). Interpretasi terkini dari teori tersebut adalah siswa seharusnya diberi tugas-tugas kompleks, sulit tapi realistik, kemudian diberi bantuan secukupnya untuk menyelesaikan tugastugas tersebut.

$$
\text { Berdasarkan paham }
$$
konstruktivisme, diperoleh beberapa prinsip pembelajaran. Observasi dan mendengar aktivitas matematika siswa merupakan sumber yang kuat dan petunjuk untuk mengajar, untuk penyusunan kurikulum, dan untuk menyusun cara mengevaluasi pertumbuhan pengetahuan siswa (Steffe \& Keiren, 1995). Dalam pendekatan konstruktivis aktivitas matematika dapat diwujudkan melalui tantangan masalah, tugas-tugas kelompok, atau diskusi kelas dengan topik-topik yang biasa dibahas dalam kelas konvensional. Pada kelas konstruktivis pembelajaran selalu berorientasi pada "problem centered approach" dengan guru dan siswa terikat dalam pembicaraan yang memiliki makna matematika. Beberapa ciri tersebut akan mendasari proses pembelajaran dengan pendekatan konstruktivisme.

Konsep pembelajaran kontruktivis didasarkan pada hasil kerja para ahli psikologi dan peneliti yang tertarik pada paham konstruktivisme. Para ahli ini berpendapat bahwa ketika siswa menyelesaikan tugas-tugas, ketika itu pengetahuan matematika dikonstruksi secara aktif (Wood, Cobb dalam Suherman et al., 2001). Ahli 
konstruktivis lain mengatakan bahwa dalam perspektif konstruktivis, belajar matematika bukanlah suatu proses "pengepakan" pengetahuan secara hatihati, melainkan tentang bagamana "mengorganisir" aktivitas siswa, ketika kegiatan ini diinterpretasikan secara luas dalam aktivitas dan berpikir konseptual siswa (Cobb dalam Suherman et al., 2001). Jadi belajar matematika adalah suatu proses pengkonstruksian pengetahuan matematika oleh siswa secara aktif.

Para ahli konstruktivis sepakat bahwa belajar matematika melibatkan manipulasi aktif dari pemaknaan, bukan hanya bilangan dan rumus-rumus saja. Mereka menolak paham bahwa matematika dipelajari dalam satu koleksi berpola linier. Setiap tahap pembelajaran melibatkan suatu proses penelitian terhadap makna dan penyampaian keterampilan hafalan yang menjamin siswa menggunakan keterampilan intelegensinya dalam setting matematika.

Hal penting yang tidak boleh diabaikan adalah, ketersediaan lingkungan belajar agar siswa dapat mencapai konsep dasar, ketrampilan algoritma, proses heuristic dan kebiasaan bekerja sama dan berefleksi. Terkait dengan proses belajar, Cobb (dalam Suherman et al., 2001) menegaskan bahwa belajar dipandang sebagai suatu proses aktif dan konstruktif yang mengkondisikan siswa mencoba menyelesaikan masalah yang muncul sebagaimana yang mereka ikuti secara aktif dalam latihan matematika di kelas.

Hal mendasar dalam belajar matematika menurut paham konstruktivisme adalah pendekatan jawaban "tak terduga" dengan suatu taktik yang cerdik dalam mempelajari karakter, keaslian, cerita dan implikasinya. Belajar matematika menurut paham ini adalah proses pemecahan masalah. Paham ini memfokuskan pada proses belajar siswa secara individual untuk aktif mengkonstruksi realitas matematika mereka sendiri (Cobb dalam Suherman et al., 2001). Aplikasi teori ini dalam pembelajaran adalah guru mengkondisikan siswa melakukan aktivitas fisik maupun mental dalam pembelajaran

\section{Komunitas Inquiry Matematika}

\section{a. Pengajaran dan Pembelajaran Inquiry}

Pengajaran atau pembelajaran inquiry telah dikenal di Indonesia cukup lama. Namun demikian kajian tentang model pembelajaran inquiry sampai saat ini masih cukup relevan terutama untuk 
mata pelajaran matematika dan IPA. Kajian tersebut bukan hanya dititikberatkan pada bagaimana menerapkan model ini dalam proses pembelajaran, tetapi juga mengkaji tentang bagaimana menciptakan atau membangun komunitas inquiry dalam proses pembelajaran.

Menurut pandangan Bell (1981:340), inquiry adalah sebuah proses investigasi (pencarian terfokus) dan pengujian suatu situasi dalam suatu pemerolehan informasi dan kebenaran (truth). Berdasarkan pada pandangan tersebut peranan inquiry sangat penting dalam memperluas dan mengorganisasikan pengetahuan matematika.

Empat langkah (stages) yang harus dilalui dalam menerapkan inquiry dalam proses pembelajaran, yaitu: (1) Merumuskan permasalahan; (2) mengembangkan prosedur dan mengumpulkan informasi yang relevan dengan situasi atau permasalahan yang dihadapi; (3) memanfaatkan prosedur dan informasi pada langkah ke-2; dan (4) menganalisis dan mengevaluasi proses inquiry untuk mengembangkan proses investigasi situasi lain. Langkah-langkah proses inquiry cukup relevan dengan model umum pemecahan masalah, yaitu: (1) menemukan problem umum; (2) menyatakan kembali problem tersebut dalam bentuk yang daaaapat diselesaikan (solvable); (3) merumuskan metode untuk memecahkan problem; memecahkan problem; dan mengevaluasi solusi dan strategi penyelesaian.

Dilihat dari langkah-langkahnya, proses inquiry dapat dikatakan sebagai metode pembelajaran inisiatif-mandiri (self-inisiated) yang dapat diterapkan secara individual atau dalam kelompok kecil. Sedangkan situasi pembelajaran inquiry matematika yang ideal menurut Bell (1981:340) adalah ketika para siswa merumuskan suatu prinsip matematika lain yang baru dengan kerja mandiri atau dalam kelompok kecil dengan arahan yang minimal dari guru. Namun dalam kenyataannya, arahan guru yang minimal ini tidak selalu mendukung kelancaran proses inquiry. Tidak sedikit terjadi bahwa, proses inquiry matematika sering berjalan tidak terarah sebagaimana yang diharapkan. Maka tindakan-tindakan penting guru sebagai alat untuk mengarahkan proses inquiry sangat diperlukan. Karena peran guru dalam proses inquiry adalah sebagai moderator atau fasilitator, dan kedua peran ini perlu diterjemahkan dalam tindakan yang lebih spesifik.

\section{b. Membangun Komunitas Inquiry} Matematika 
Sebagaimana yang telah penulis kemukakan, guru perlu menterjemahkan peran moderator dan fasilitator dengan melakukan tindakan-tindakan khusus untuk mengarahkan proses inquiry matematika. Pada bagian ini akan dibahas beberapa hal terkait dengan tindakan khusus apa yang mungkin dilakukan guru untuk menciptakan komunitas inquiry dalam proses pembelajaran matematika. Teori sosio cultural menjadi landasan fundamental atau kerangka kerja (frame work) untuk memayungi praktek pengajaran inqury. Secara spesifik gagasan tentang zone of proximum development (ZPD) dilibatkan sebagai suatu kerangka kerja (frame work) yang fundamental, untuk menjelaskan pembelajaran sebagai upaya meningkatkan partisipasi siswa dalam komunitas inquiry matematika. Pada perkembangan terakhir, para pengambil kebijakan pendidikan maupun para peneliti pendidikan terpanggil untuk melakukan perubahan yang berarti dalam pendidikan matematika, kepada suatu cara bagaimana matematika dipikirkan oleh siswa. Sebagai contoh adalah, Amerika Serikat, Beberapa dokumen kurikulum yang sangat penting telah dihasilkan oleh NCTM, dengan mempertimbangkan kepada perbaikan pada proses problem solving, reasoning, dan communcation.(NCTM, 1989; 2000)
Dalam kaitannya dengan membangun komunitas inquiry, ada empat hal penting yang perlu mendapat perhatian, yaitu: (1) Tindakan Khusus apa yang dapat dilakukan guru untuk menciptakan komunitas inquiry dalam proses pembelajaran matematika di Secondary School; (2) Bagaimana guru memberikan rangsangan awal (inisiated) siswanya ke dalam menciptakan suatu budaya inquiry; (3)Praktek pembelajaran jenis apa yang dapat mengkondisikan partisipasi aktif siswa; dan (4) Tindakan spesifik apa yang dilakukan guru, untuk memunculkan atau meningkatkan (improve) partisipasi siswa.

\section{Sosio Cultural sebagai Landasan Fundamental}

Setidaknya, ada dua pendapat yang relevan dalam kajian tentang sosiokultural dalam proses pembelajaran di kelas. Menurut Forman (2003), pandangan sosiokultural dapat memberikan suatu rasionalisasi teoritis untuk suatu perubahan dalam upaya mereformasi pendidikan matematika. Pendekatan sosiokultural dibedakan menurut frame work (kerangka kerja) teoritis yang lain bersama asosiasiasosiasinya, dengan sekolah Vygotsky dalam aktivitas berpikir, yang mengklaim bahwa kegiatan berpikir manusia adalah 
aktivitas yang inheren (melekat/terjiwai) secara alami.

Berdasarkan pendapat Forman tersebut, teori sosiokultural menawarkan sebuah cara memajukan pemahaman dan hubungan yang mendasar antara proses pebelajaran dengan hasil pembelajaran. Pendapat ini menunjukkan pula tentang bagaimana pembelajaran matematika dikomunikasikan dalam konteks sosial.

Sedangkan Lave\&Winger (1991) berpendapat bahwa pengajaran dan pembelajaran matematika dipandang sebagai suatu suatu aktivitas sosial dan komunikatif yang sesuai dengan formasi komunitas pembiasaan matematika di kelas. Dalam pandangan ini para siswa mencocokan secara progressif dan memerankan nilai-nilai epistemologis dalam komunitas matematika yang lebih luas.

\section{Community of Practice ( Komunitas Pembiasaan) Matematika}

$\begin{array}{rcr}\text { Semua } & \text { proses } & \text { kegiatan } \\ \text { pembelajaran } & \text { matematika } & \text { adalah }\end{array}$
komunitas pembiasaan matematika, tetapi komunitas kegiata pembelajaran di kelas berbeda menurut jenis pembiasaan pembelajaran yang yang tersusun dan diterima sebagai sesuatu yang sudah tepat oleh guru dan siswa (Boaler, 1999). Sebagai contoh fenomena ini adalah: Dalam proses pembelajaran matematika di kelas dengan metode tradisional, penggunaan buku teks sangat mendominasi proses pembelajaran. Partisipasi efektiv yang melibatkan siswa untuk melihat dan mendengar prosedur ketrampilan prosedur atau algoritma matematika yang didemonstrasikan guru., selanjutnya mempraktekkan ketrampilan itu dengan mengerjakan soal-soal latihan atau melengkapi lembar kerja siswa

Metode mengajar tradisional mendorong siswa melakukan memorisasi (pengingatan) maupun pengulangan (reproduction) prosedur atau langkahlangkah matematika. Pendekatan tersebut dapat dipertentangkan dengan pendekatan community of practice yang lebih terbuka dalam mereformasi orientasi kegiatan pembelajaran matematika, seperti diskusi dan kolaborasi, yang dinilai sebagai suatu tantangan intelektual, dan lebih dari sekedar menyandarkan kepada guru sebagai pemegang otoritas proses pembelajaran.

Pendekatan ini juga dapat membangun kepercayaan dalam mereformasi kerangka pembelajaran dalam kelas sebagai partisipasi dalam suatu komuniatas yang dicirikan secara praktis dalam inquiry matematik. Di sini, siswa dibiasakan untuk belajar berbicara dan bertindak matematis dengan berpartisipasi dalam kegiatan diskusi matematika, serta memecahkna 
permasalahan yang masih asing (baru) atau tidak rutin (Richard, 1991), sehingga kegiatan pembelajaran di kelas dapat dideskripsikan sebagai "Komunitas Inquiry Matematika".

\section{ZPD sebagai Framework Analisis}

\section{Proses Inquiry Matematika}

Dalam kaitannya dengan ZPD, ada tiga hal penting yang dapat dikaitkan dengan interaksi yang terjadi dalam praktek pembelajaran di kelas.

\section{a. Interaksi guru-siswa: ZPD sebagai} suatu aktifitas scaffolding

Alternative pertama dari framework ini dibangun sesuai definisi asli ZPD seperti yang digagas oleh Vygotsky, yaitu sebagai jarak antara kemampuan problem solving anak ketika ia bekerja sendiri dan kemampuan problem solving dengan bantuan partner yang lebih menguasai, seperti guru atau teman sebaya.

Istilah scaffolding menjadi terassosiasi dalam interaksi, dengan guru menyusun tugas-tugas untuk merangsang siswa berpartisipasi dalam aktivitas bersama, dan mungkin pula akan berlaku sebaliknya, yaitu kemampuan siswa melebihi dari jangkauan mereka yang diperkirakan. Sebagai contoh, hasil guru menggunakan struktur dialog yang dapat diprediksi arahnya, atau menawarkan (negotiated) sebuah pembagian tugas matematika, antara guru dan murid terjadi interaksi, kemudian secara perlahan siswa dilepas untuk menyelesaikan tugas-tugasnya secara mandiri.

\section{b. Interaksi siswa-siswa: ZPD sebagai} suatu aktivitas collaborasi

Vygotsky menganalisis gagasan ZPD dengan istilah, " more equal status partner ships", ia mencatat bahwa, ketika siswa bermain bersama, mereka dapat mengatur perilakunya sendiri dan temantemannya berdasarkan pada tatanan (script) sosial yang sudah umum, dan saling bertukar sudut pandang antar satu sama lainnya.

Berdasarkan hasil penelitian pada kelompok kecil "problem solving", dapat menjelaskan, bagaimana interaksi antar siswa dengan keahlian masing-masing dapat dibandingkan (compartible) untuk $\begin{array}{lll}\text { menciptakan } & \text { suatu }\end{array}$ collaborative.Dalam kelompok kolaborative sebaya, para siswa memiliki peluang mengungkap gagasan-gagasan yang sedang mereka bangun, serta kepada pengalaman mereka sendiri dan partnernya, sebagai partisipasi aktif dalam menciptakan wawasan matematis seorang siswa.

Namun perlu diperhatikan bahwa, tidak semua hasil konstruksi siswa adalah valid, meskipun tidak lengkap, atau konstruksi tidak dapat diterima, tetapi 
dapat muncul sebuah landasan dan aktivitas pembelajaran di kelas serta diskusi dengan interpretasi yang berbeda.

\section{Konsep Informal - Konsep Formal: ZPD sebagai suatu \\ Interweaving}

Aspek ketiga dari ZPD diturunkan oleh teoriritisasi Vygotsky dalam hubungannya dengan sekolah dan akses yang disediakan oleh sekolah formal agar lebih terorganisir hingga mencapai bentuk formal dari suatu pengetahuan. Dia membedakan dua tipe konsep yang berhasil dibangun siswa, yaitu: konsep sehari-hari atau konsep spontan yang muncul dari pengalaman yang ada dalam komunitas anak yang tidak termediasi.; dan (2) konsep teoritis atau scientific (formal) yang telah dielaborasikan dan dipertajam dalam waktu yang cukup untuk membentuk sistem pemahaman yang koheren. Di sini, ZPD diartikan sebagai jarak antara gagasan sehari-hari (informal) siswa dengan konsep yang terformalkan (formalized concept).

Pengetahuan yang matang (mature) diperoleh siswa dengan cara mengabungkan konsep sehari-hari siswa dengan konsep-konsep scientific, dan bukan dcapai dengan penempatan pembentuk (former) seperti dalam transmission model, tetapi dengan interweaving (penjalinan) dua bentuk konseptual sebagai representasi dari kultur matematik dalam proses pembelajaran. Di sini, Guru memiliki kapasitas untuk melihat gagasan-gagasan siswa yang tersambungkan dengan bahasa dan konsep-konsep dalam komunitas matematisi yang lebih luas.

Tiga aspek ZPD tersebut dapat digunakan sebagai alat analisis berbagai praktek pengajaran dan pembelajaran yang digunaklan oleh seorang guru. dalam membantu siswa mengambil caracara yang tepat untuk mengetahui, berbicara, dan bertindak, yang merupakan karakteristik dari komuinitas inquiry matematik.

Dalam sebuah penelitiannya, dengan menggunakan 'catatan lapangan', dan video - audio recording', selama 4 (empat) minggu pertama observasi kelas, ditemukan 9 (sembilan) katagori yang dinyatakan sebagai 'pernyataan tindakan' guru, yaitu : (1).Guru memodelkan 'berpikir matematis'; (2) Guru meminta siswa untuk melakukan klarifikasi, elaborasi, dan justifikasi jawaban serta strategi mereka.; (3) Guru menekankan kepada 'ke-dapatdimengerti-an' suatu pengetahuan atau ketrampilan; (4) Guru membuat rekomendasi yang eksplisit kepada aturan-aturan matematis dan persimbolan; (5) Guru mendorong siswa untuk melakukan 'refleksi', 'self- 
monitoring', dan 'self-checking'; (6)

Guru menggunakan gagasan siswa sebagai 'starting point' untuk mengawali diskusi kelas; (7) Guru men-structure kegiatan berpikir sisw; (8) Guru mendorong terjadinya diskusi 'eksploratory' yang berhubungan dengan penyelidikan untuk suatu penemuan; dan (9) Guru men-structure interaksi sosial siswa.

Dalam komunitas inquiry guru perlu meminta siswa untuk kepentingan klarifikasi, elaborasi dan pembenaran respon dan strategi yang mereka plih. Fakta-fakta tindakan guru yang mendukung upaya ini, antara lain: (1).Guru menggunakan pertanyaan untuk mendatangkan proses interaksi; (2) Guru mendorong siswa lain untuk memberikan komentar, untuk merespon kontribusi pembicara (siswa) sebelumnya; (3) Guru mendorong argumentasi antar siswa, tanpa dimediasi oleh guru; dan (4) Guru menuntut para siswa untuk memberikan pertanggungjawaban atas validasi penyelesaian (solusi) yang telah dihasilkan.

Dalam membangun komunitas inquiry perlu diperhatikan lebih mendalam tentang wawasan teoritis atas peran guru dalam meng-initiating (menstimulasi) kegiatan atau partisipasi siswa, serta memprakarsai siswa dalam membangun budaya inquiry matematik.
Dari proses inquiry dapat diidentifikasi perilaku matematis dan harapan pedagogis yang mendasari tindakan (action) guru, dan bagaimana tidakan ini dicocokkan dengan kepentingan siswa.

Dua asumsi pertama, mengidentifikasi sebuah cara umum praktek inquiry matematika yang diharapkan guru tentang partisipasi siswa. , sedangkan tiga asumsi berikutnya berkorespondensi dengan interpretasi pembelajaran dala ZPD yang telah peneliti uraikan (paparkan) sebagai suatu scaffolding, colaborating, dan interweaving. Peneliti memeriksa keakuratan (kemasukakalan) dari pernyataan-pernyatan ini dengan membandingkan dengan data yang sudah diperoleh melalui 'wawancara guru dan siswa serta melalui observasi kegiatan pembelajaran di kelas', dan melanjutkan analisis ini sampai pada hasil perolehan data pada tahun ke-2 penelitian, sebagaimana yang telah peneliti hantarkan pada observasi dan wawancara lebih lanjut.

Di samping itu perlu mempersiapkan siswa dalam melakukan tindakan (action) yang relevan dalam proses inquiry matematika sesuai dengan yang didemonstrasikan dan diharapkan oleh guru.

Menciptakan Komunitas Inquiry 
Untuk memahami, bagaimana suatu komunitas inqury dibangun pada suatu periode tertentu, perlu diuji kedua praktek pengajaran yang dijalankan guru, untuk mengkreasi suatu variasi ZPD, maupun, mengubah jenis partisipasi siswa di luar partisipasi yang ada.

Pernyataan tersebut relevan dengan hasil study Goss (2004) yang menemukan bahwa: (1) Penelitian ini, berhasil menjelaskan, bagaimana suatu komunitas pembelajaran di kelas dikreasikan dalam bentuk inquiry matematik, pada tingkat senior secondary school grade 11 dan 12 (kelas 2 dan 3 SMA), dengan menekankan kepada aspek penalaran, komunikasi, dan problem solving; (2) mengidentifikasi berbagai cara guru dalam menginisiasikan proses inquiry matematik. Langkah-langkah tindakan guru tersebut merupakan hasil kreativitasnya untuk mengkreate suatu proses pembelajaran matematika yang mengkondisikan terjadinya komunitas inqury matematik; (3) Selama berada dalam proses study (penelitian ), guru mitra telah melibatkan sikap matematis yang didemonstrasikan dalam proses pembelajaran, dan dengan menguraikan ide-ide yang lebih abstrak yang mengacu kepada konjektur, justifikasi, dan pembuktian.
4. Strategi ARIFIN sebagai alat untuk membangun Komunitas

\section{Inquiry Matematika}

Salah satu hasil kajian penulis terhadap paham konstruktivisme adalah gagasan tentang pembelajaran matematika berbasis aktivitas (Activity Base Learning of Mathematics). Dalam konsepsi ini penulis memandang bahwa pembelajaran matematika hendaknya dikelola menurut rangkaian kegiatan yang terdiri dari enam tahap, meliputi : (1)Aksi (action), (2) Refleksi (reflection), (3)Interaksi (Interaction), (4) Formalisasi (formalisation), (5) Implementasi (implementation), dan diakhiri dengan tahap (6). Narasi (narration). Sesuai dengan urutan tahap-tahap pembelajaran yang dijalankan, pembelajaran ini dikenal dengan model "Arifin" (Arifin, 2005).

Tahap pembelajaran dalam model "Arifin" tersebut mengikuti garis yang ditunjukkan oleh grafik Kurva Normal, dimulai dari mengajak siswa melakukan aksi yang dapat menghadirkan situasi nyata dari fenomena alam (action stage), dari sini siswa dibawa kepada aktivitas berpikir yang lebih tinggi yaitu refleksi. Selanjutnya untuk mengklarifikasi hasil refleksi, diperlukan proses interaksi (take of phase). Pada tahap ini matematisasi horizontal mewarnai aktivitas belajar siswa. 
Selanjutnya siswa dibawa ke tahap berpikir yang lebih tinggi lagi (flying phase) melalui kegiatan formalisasi. Di sini siswa bebas melakukan manipulasi obyek-obyek formal matematika, karena di "dunia matematika" ini siswa terbebas dari ikatan konteks, di wilayah ini peran matematisasi vertical sangat dominan. Pada tahap inilah inti pembelajaran matematika dilakukan. Menurut Dienes (dalam Suherman et al., 2001), formalisasi merupakan tahap pembelajaran konsep matematika yang terakhir. Pada tahap ini siswa diminta untuk menyebutkan sifat-sifat konsep yang ada, kemudian merumuskan sifatsifat baru dari konsep tersebut. Sebagai contoh, anak-anak yang telah mengenal dasar-dasar aksiomatik, harus mampu menyebutkan sifat-sifat yang berlaku pada aksioma tersebut dan merumuskan (membuktikan) teorema yang diturunkan dari aksioma tersebut.

Setelah siswa dinilai cukup memahami obyek-obyek matematika, guru dapat melanjutkan aktivitas pembelajaran dengan mengajak siswa menerapkan pengetahuan yang baru diperoleh dalam menyelesaikan permasalahan teoritis (formal problem) atau permasalahan realistis (kontekstual problem) melalui kegiatan implementasi. Akhirnya guru meminta siswa untuk mengungkapkan atau menceritakan kembali pengetahuan barunya melalui kegiatan elaborasi dengan teman sebangku atau satu kelompok, atau cukup dengan cara menuliskannya pada kertas buram,untuk dicocokkan kebenarannya melalu panduan guru. Tahap ini dapat dikatakan sebagai tahap narasi (narration) atau tahap pemantapan.

Berdasarkan karakteristik pada masing-masing tahap pembelajaran dalam strategi ARIFIN, dapat dikemukakan bahwa strategi ini dapat dimanfaatkan sebagai konduktor dalam upaya membangun komunitas inquiry matematika. Karena tahap-tahap pembelajaran seperti action, reflection, interaction, formalization, interconnection, dan dan narration memiliki peran yang cukup berarti dalam menstimuli proses inquiry matematika.

Walaupun

objek-objek matematika bersifat abstrak, pengajarannya dapat diawali dengan menghadirkan situasi nyata dari fenomena alam. Salah satu cara yang relevan uantuk maksud tersebut adalah mengkondisikan siswa melakukan aksi. Aksi yang dilakukan siswa dapat berupa rangkaian kegiatan yang di samping melibatkan mental juga melibatkan aktivitas fisik. Aksi tersebut merupakan respon siswa terhadap intruksi guru, seperti melakukan peragaan tertentu, 
sementara siswa lainnya mengamati peragaan tersebut. Selain melibatkan aktivitas mental seperti memahami permasalahan, dan berusaha mencari pemecahannya, aksi dapat pula berupa pengamatan terhadap obyek yang akan diidentifikasi sifat-sifat matematisnya.

Refleksi. merupakan salah satu tahap dalam pembelajaran berbasis aktivitas. Gofree dan Dolk (dalam Sabandar, 2001) menyatakan bahwa refleksi menunjuk kepada suatu situasi yang diamati, dikenali, direnungkan, serta dianalisis dengan berdasarkan pengalaman serta pengetahuan seseorang. Dalam pembelajaran matematika, refleksi dapat dimunculkan ketika siswa dihadapkan kepada suatu fenomena atau peristiwa yang akan diidentifikasi sifatsifat matematisnya. Proses pembelajaran yang menekankan pada aktivitas berpikir reflektif mengantarkan siswa mencapai keberhasilan dalam pembelajaran. Siswa yang berpikir reflektif selalu berpikir tentang apa yang mereka amati atau mereka lakukan, dengan terlebih dahulu mengumpulkan informasi sebanyakbanyaknya untuk kemudian menganalisisnya sesuai dengan sasaran yang ingin dicapai. Hampir setiap pembelajaran selalu melibatkan berpikir reflektif. Hal tersebut sesuai dengan penjelasan Reed (dalam Johar, 2002) bahwa berpikir reflektif merupakan sentral dalam setiap proses pembelajaran. Gejala-gejala fisik yang tampak pada siswa yang melakukan berpikir reflektif antara lain, mencatat tentang hubunganhubungan antar informasi yang mereka amati, berbicara dengan diri mereka sendiri dan merekam gagasan-gagasan merka dalam pikirannya. Pada gejala yang terakhir tersebut, siswa melakukan komunikasi dengan dirinya sendiri sebagaimana yang dikemukakan Skemp (1982:27), "Reflecting is communicating within oneself'. Terkait dengan komunikasi dalam buku Principles and Standards for School Mathematics dikemukakan bahwa "Reflection and communication are interwined process in mathematics learning"(NCTM, 2000:17). Langkah berikutnya adalah interaksi. Berdasarkan proses interaksi tersebut diharapkan siswa dalam kondisi siap memasuki dunia formal matematika (world of mathematics) melalui proses formalisasi.

Proses pembelajaran yang benarbenar lepas dari konteks dunia nyata adalah formalisasi. Pada tahap ini siswa akan diajak untuk memanipulasi objekobjek matematika melalui proses abstraksi, idealisasi atau manipulasi. Pada tahap ini diharapkan transfer pengetahuan formal matematika terjadi pada diri siswa. Kondisi yang diharapkan terbentuk dari proses ini antara lain: 
(1).konsep-konsep matematika terbentuk, (2).fakta-fakta dan simbol-simbol dipahami, (3).ketrampilan, prosedur atau skill dapat dikuasai, dan (4). prinsipprinsip matematika dipahami. Cara yang paling efektif dan praktis dilakukan oleh guru pada tahap ini adalah menggunakan teknik pengajaran langsung (dirrect instruction). Pada tahap ini siswa dapat melakukan abstraksi (abstacting), idealisasi (idealizing), simbolisasi (simbolizing), generalisasi (generalizing), dan formulasi (formulating) (Farrell \& Farmer,1980). Langkah berikutnya, setelah formalisasi adalah implementasi.Pada tahap ini siswa harus mampu mengkaitkan pengetahuan barunya dengan permasalahan teoritis atau realistis dan diharapkan dapat memecahkan masalah secara bermakna.

Langkah terakhir dari Model ARIFIN adalah narasi (narration). Aktivitas ini untuk memantapkan pengetahuan yang baru diperoleh siswa. Pada tahap ini guru seharusnya mengarahkan aktivitas siswa untuk menceritakan kembali pengetahuan matematika yang baru diperoleh. Kegiatan narasi ini dapat dilakukan secara klasikal dengan menunjuk secara random beberapa siswa untuk melakukan narasi di depan kelas, atau cukup berada pada tempat duduknya. Dapat pula dilakukan secara individual dengan meminta siswa menuliskan ikhtisar pengetahuan barunya pada kertas buram,selanjutnya guru mengambil sekitar 2 sampai 5 tulisan untuk dibahas di depan kelas.

\section{PENUTUP}

Model Pembelajaran "ARIFIN" dirancang sebagai tahapan yang runtut, melibatkan matematisasi horisontal maupun matematisasi vertikal. Filsafat pembelajaran konstruktivisme maupun behavioristik dapat diterapkan secara proporsional tergantung pada situasi maupun materinya. Secara umum dapat penulis kemukakan bahwa aspek-aspek pembelajaran yang mengacu kepada filsafat konstruktivisme lebih dominan pada tahap aksi, refleksi, interaksi, dan narasi. Tahapan tersebut dapat dimanfaatkan sebagai konduktor dalam menciptakan komunitas inquiry matematika dalam proses pembelajaran di kelas.

Penulis menyadari bahwa berpikir refleksi sangat multi interpretatif dan memiliki fleksibelitas dalam berbagai konteks. Dalam pembelajaran berbasis aktivitas, penulis hanya membatasi pada reflektif atas tindakan (action) yang dilakukan pada awal pembelajaran. Refleksi tersebut dapat dilakukan terhadap obyek-obyek fisik yang dijadikan sasaran aksi (aksi mental) yang 
oleh Piaget disebut "empirical abstraction". Dan refleksi terhadap obyek-obyek mental yang dijadikan sasaran aksi (mental action) berupa permasalahan teoritis (matematika formal) maupun pertanyaan yang dikemukakan guru, yang oleh Piaget disebut "reflective abstraction"

Tahap-tahap sebagaimana yang penulis maksudkan dalam model pembelajaran ini, tidak selalu berjalan satu rangkaian dalam sekali tatap muka. Tetapi rangkaian kegiatan ini dapat terjadi lebih dari satu kali dalam sekali tatap muka (pertemuan) sesuai dengan kondisi siswa, tujuan pengajaran, dan pengetahuan matematika yang ingin dibangun pada diri siswa. Dengan kata lain, model pembelajaran ini tidak mengacu pada satuan waktu tatap muka tetapi lebih mengacu kepada pengetahuan formal matematika yang ingin dibangun pada diri siswa. Apabila suatu konsep, prinsip, atau skill yang dibangun sudah melalui rangkaian aktivitas pada model pembelajaran ini, maka pembelajaran dapat dilanjutkan untuk konsep, prinsip, atau skill berikutnya, demikian seterusnya. Tetapi tidak menutup kemungkinan ada beberapa pengetahuan formal matematika yang dapat sekaligus dijalankan melalui tahap-tahap dalam model pembelajaran ini.

\section{DAFTAR PUSTAKA}

Arifin, Z. (2005). Strategi "ARIFIN" Sebagai Salah Satu Alternatif Pembelajaran Matematika dalam Perspektif Konstruktivisme. Makalah Disampaikan dalam Diskusi Terbatas Mahasiswa S-1 Pendidikan Matematika Universitas Islam Darul Ulum Lamongan.

Amin. S. M. (2002). PMRI: Upaya Pencerahan Pembelajaran Matematika. Majalah Ilmiah Himpunan Matematika Indonesia (MIHMI), Vol. 8, No. 3 Tahun 2002.

Asmin (2003). Implementasi Pembelajaran Matematika Realistik (PMR) dan Kendala yang Muncul di Lapangan. Jurnal Pendidikan dan Kebudayaan No. 044 September 2003. Departemen Pendidikan Nasional

Bell, F.(1981). Teaching and Learning Mathematics (In Secondary School). Dubuque, Iowa: Wm. C. Brown Company Publishers

Confrey, J. (1990). What Constructivism Implies for Teaching. In R.B.Davis, C.A. Maher \& N.Noddings (Eds.), Constructivist Views on The Teaching and Learning of Mathematics (pp. 107-124). Reston. Virginia: NCTM.

Davis, D. R. (1960). The Teaching of Mathematics. Reading, Massachusetts, U.S.A., London, England: Addison-Wesley Publishing Company.

Farrell, M.A., Farmer, W.A. (1980). Systematic Instruction in Mathematics. for The Middle and High School Years. Reading, Massachusetts, U.S.A., London, 
England: $\quad$ Addison-Wesley

Publishing Company.

Goldin, M.S.,Kim, San,\&Singer, M.(1999). What The Teacher's Hand Tell the Student's Mind About Math. Journal of Educational Psychology, Vol. 9, No. 4, 720-730. American Psychology Association. Inc.

Goss, Merillyn.(2004). Learning Mathematics in a Classroom Community of Inquiry. Journal for Research in Mathematics Education, 2004, vol. 35. No. 4 , 258-291.

Heuvel, Van den, Panhuizen (2003). Gudes for Didactical Decicion Making in Primary School Mathematics education: The Focus on The Content Domain of Estimation. Opplaeringen, 1, 139152.

http://www.geocities.com/nikzafri/pedagogi.html

Http://www.eduplace.com/rdg/res/asses/o pport.html.(1997). Self-assesment Op-purtunities Houghton Mifflin Company.

Inagaki, K., Morita, E., Hatano, G.(1999). Teaching - Learning of Evaluative Criteria for Mathematical Arguments Through Classroom Discourse: A CrossNational Study. Mathematical Thinking and Learning, I (2), 93111

Johar, Rahmah. (2002). Refleksi dalam Pembelajaran Matematika. Proceeding National Science Education Seminar. State University of Malang (UM), 5 Agustus 2002.

Lobato, J., Clarke, D., Ellys, A. Burns.(2005).
Eliciting in Teaching: A Reformulation of Telling. Jurnal for Research in Mathematics Education, Vol. 36, No. 2, 101-136 Meyer, Margaret. T. (1999). Multiple Strategies $=$ Multiple Challenges. Mathematics Teaching In Middle School. 4 (8), page 519-523

Matlin, M.W.(1994). Cognition( $3^{\text {rd }}$ edition). Harcourt Brace Publishers: USA

National Council of Teachers of Mathematics. (2000). Principles and Standards for School Mathematics. Reston, VA : Author.

Reed, Arthea J.S. Bergemann, Verna E. (2001). A Gude to Observation, Participation and Reflection in Classroom. Fourth Edition. Boston. Mc.Graw Hill.

Ruseffendi, E.T. (1991). Pengantar kepada Membantu Guru Mengembangkan Kompetensinya dalam Pengajaran Matematika untuk Meningkatkan CBSA. Bandung: Tarsito Bandung.

Sabandar, Jozua. (2001). Refleksi dalam Pembelajaran Matematika Realistik. Makalah Disajikan pada Workshop Pengembangan Pembelajaran RME untuk SD di PPPG Matematika Yogyakarta Tanggal 4-11 Juli 2001.

Simon,M. Tzur,R.,Heinz, K.Kinzel, M.(2004). Explicating a Mechanism for Conceptual Learning: Elaborating the Construct of Reflectif Abstraction. Jurnal for Research in Mathematics Education, Vol. 35, No. 5, 305-329. Skemp, Richard. (1982). The Psychology of Learning Mathematics. London: Penguin Book. 
Slavin, Robert E. (1997). Educational Psychology. Theory and Practice. Fifth Edition. Boston: Allyn and Bacon.

Sobel, Max. A. \& Maletsky, Evan M. (1988). Teaching Mathematics, A Source Book of Aids, Activities, and Strategies. Boston-LondonTotonto-Sydney-Tokyo-Singapore: Allyn \& Bacon

Steffe, L.P., \& Keiren, T. (1995). Radical Constructivism and Mathematics Education. Journal for Research in Mathematics Education, 25(6),713733.
Stein, M.K \& Smith, M.S.1998. Mathematical Task as a Frame work for Reflection: for Research to Practice. Mathematics Teaching in The Middle School. 3(4), 268-275. Suyatno, M.(1988).“Minat Siswa terhadap Matematika Perlu Ditumbuhkan". Jakarta: Kompas. 1 februari 1988. 